Стрельбицький М. П., д.ю.н., професор ${ }^{1}$; Філіппов С. О. к.психол.н., доцент ${ }^{2}$

1 - Національна академія Служби безпеки України, Київ;

2 - Національна академія Державної прикордонної служби України імені Богдана Хмельницького, Хмельницький

\title{
Зміна конфігурації системи протидії транскордонним загрозам на кордонах Свросоюзу
}

Резюме. Основна увага в статті приділяється заходам протидії транскордонним загрозам в ЄС, зокрема: створення Європейської прикордонної і берегової охорони на платформі FRONTEX; застосування сил і засобів НАТО в суто поліцейській операції в Егейському морі; механізм інформаційної взаємодії між прикордонними відомствами держав-членів СC - EUROSUR; операції міжнародних інституцій, спрямовані на сприяння прикордонним службам.

Ключові слова: транскордонна злочинність, організація нелегальної міграції, система протидії транскордонним загрозам, Свропейська прикордонна і берегова охорона, НАТО.

Постановка проблеми. Глобалізація $\epsilon$ об’єктивним явищем сучасного світу. Наслідком глобалізації всіх світових відносин, як економічних, фінансових, так $\mathrm{i}$ технологічних, є глобалізація транскордонної злочинності. Очевидно, що інтернаціоналізація злочинності в умовах глобалізації у першу чергу інтенсифікуе транскордонну злочинність, впливаючи як на iї кількісні показники, так і на показники, що визначають рівень її суспільної небезпеки. Це, у свою чергу, обумовлює необхідність інтернаціоналізації системи протидії транскордонній злочинності, оскільки контролювати іiі на рівні окремих держав неможливо. При цьому міжнародна правоохоронна діяльність у СС тривалий час характеризувалася інертністю, реактивним способом реагування на транскордонні криміногенні загрози, неузгодженістю мети та засобів реалізації кримінологічної політики у кожній із держав, що зменшувало здатність такого міждержавного об'єднання як Європейський союз до ефективної протидії транскордонним формам злочинності.

Аналіз останніх досліджень. Протидія новим транскордонним загрозам у Європі не $\epsilon$ новим предметом досліджень кримінологів і представників суміжних напрямів науки як в Україні, так i за кордоном. Наприклад, теоретичним та прикладним проблемам протидії організованій злочинності в Європейських країнах присвячена робота О. Шостки. Порівняльно-правове дослідження правоохоронної діяльності в країнах $\mathrm{CC}$ провів А. Білас, механізм правового регулювання діяльності ЄС у сфері протидії транскордонним злочинам розкрито у роботі А. Павленка. Водночас, у дослідженнях українських авторів проблематика інституційної побудови системи протидії транскордонним загрозам висвітлена фрагментарно та без урахування нових чинників (таких як міграційна криза в Свропі).

Особливе значення для нашого дослідження мають публікації перших авторів, що проаналізували потенційну роль у протидії транскордонним загрозам новоствореної прикордонної та берегової охорони ЄC Sergio Carrera та Leonhard den Hertog.

Мета статті. Розглянути у динаміці структурну конфігурацію інституційної системи протидії транскордонним загрозам на зовнішніх кордонах Євросоюзу.

Виклад основного матеріалу. Лідери двадцяти семи держав Євросоюзу у Римській декларації, яка була підписана на ювілейному саміті присвяченому 60-річчю Римських угод, визначили чотири напрями зосередження основних зусиль. Серед цих чотирьох пріоритетів на першому місці - забезпечення "надійної і безпечної Європи: союзу, де всі громадяни відчувають себе в безпеці та можуть вільно пересуватися; де зовнішні кордони надійно охороняються, а міграційна політика $€$ відповідальною, ефективною та стійкою 3 повагою до міжнародних норм; де протидіють тероризму та організованій злочинності [1-2]. Низка кризових явищ у цій сфері продемонструвала проблеми, на які звертають увагу дослідники [3]. Зокрема, вказується на те, що у “міграційній" кризі, що періодично загострюється в ЄC 3 моменту створення Агентства у 2004 p. "рішення" найчастіше полягало в збільшенні його бюджету, без надання агентству відповідних оперативних засобів та компетенції для “засвоєння” цього фінансування. Наприклад, 3 775-ти 
прикордонників, у яких виникла потреба у Frontex протягом 2015 р., агентство отримало 447. Але це не єдина і не основна проблема. Як підкреслюють S. Carrera та L. Den Hertog, загальні європейські інтереси, на захист яких працює Frontex, часто не відповідають вузьконаціональним інтересам (і не тільки країн, які перебувають на першому рубежі захисту від транскордонної злочинності, таких як Греція та Італія). 3 метою усунення цієї проблеми у 20152016 рр. ухвалено документ СС "Повідомлення щодо Свропейської прикордонної та берегової охорони, ефективного управління на зовнішніх кордонах Європи" [4].

Революційною та давно назрілою подією в ЄC (яку слід розглядати і як відповідь на міграційну кризу) є створення Європейської прикордонної і берегової охорони на платформі FRONTEX. Рішення про це було прийняте Свропейським парламентом у червні 2016 р. Нормативно оформлено повноваження новоствореної інституції Регламентом (ЕС) 2016/1624 Європейського парламенту та Ради ЄС від 14 вересня 2016 р. [5]. Офіційно почала роботу новостворена служба 6 жовтня 2016 р. Ії перші підрозділи були дислоковані на кордоні Болгарії та Туреччини. Мандат нової структури дає змогу прикордонникам брати участь в операціях і в третіх країнах, наприклад, в Північній Африці. Слід особливо підкреслити, що це перша силова структура, підпорядкована наднаціональним органам Євросоюзу, яка має свій власний оперативний персонал. Другою, якщо не революційною, то значущою подією (яка також є відповіддю на міграційну кризу) цілком можна вважати рішення про застосування сил та засобів військовополітичного Альянсу, яким є НАТО, у суто поліцейській операції в Егейському морі. Відповідно до заяви за підсумками зустрічі на вищому рівні глав держав-учасниць НАТО “масовий потік мігрантів тягне проблеми та загрози для міжнародної стабільності, безпеки та процвітання [6]. Два цих факти свідчать про міжнародну глобалізацію зусиль у питаннях протидії глобальній загрозі, якою $\epsilon$ транскордонна злочинність, пов'язана 3 нелегальним переправленням мігрантів.

Самостійне кримінологічне значення в контексті протидії транскордонній злочинності, на наш погляд, має такий механізм інформаційної взаємодії між прикордонними відомствами держав-членів Європейського союзу як EUROSUR (Система спостереження за кордонами Європи), як наднаціональний елемент охорони спільного зовнішнього кордону Європейського союзу, в основі роботи якого $\epsilon$ збір, обробка та обмін інформацією 3 метою вчасного реагування на ризики, пов'язані 3 транскордонною злочинністю, нелегальною міграцією та загибеллю мігрантів на морі.

Помітним прогрес у змінах криміногенної ситуації у транскордонній сфері стає тоді, коли система заходів протидії відповідає глобальному характеру загрози. Це можна продемонструвати на прикладі формування безпрецедентної системи міжнародних політико-правових, дипломатичних та інших (навіть військових!) заходів 3 протидії злочинності, пов'язаної 3 нелегальним переправленням мігрантів до СС [7], наведеної у табл. 1.

Слід зазначити, що FRONTEX діє не тільки на основі ситуативних змін обстановки. Агентство також практикує прогнозування імовірнісних варіантів розвитку обстановки, що відображають реалізацію політики у сфері прикордонної безпеки i динаміку змін транскордонних загроз. Ці варіанти розраховані й на відображення можливих наслідків транскордонної злочинності, що може послужити основою для іï запобігання. Зокрема, станом на 2016 р. розроблено 7 можливих варіантів, які передбачають умовно: виснаження $\mathcal{~} \mathrm{C}$, пасивність $\mathrm{CC}$, керовану різноманітність його політики, політику обмежень, різношвидкісну інтеграцію Європи, навпаки, більш тісну іiі інтеграцію в питаннях безпеки, нарешті, Свропу відкритих дверей [1, с. 56-57].

Як бачимо 3 цих назв, сценарії різняться за підходами до попередження транскордонної злочинності, за варіантами інституційного забезпечення протидії транскордонним загрозам тощо. Слід зазначити, що окремі країни СС реалізують власні рішучі кроки 3 протидії транскордонним загрозам, навіть якщо це певною мірою суперечить загальним підходам у межах ЄС. Для ілюстрації цієї тези продемонструємо досвід Угорщини. У 2015 році перед цією країною гостро постали нові транскордонні виклики, пов'язані 3 міграцією, а саме: незаконний та організований характер міграції; агресивність мігрантів, що знаходила свій прояв у деструктивних діях 3 руйнування об'єктів прикордонної інфраструктури та непокорі вимогам прикордонним підрозділів; відсутність можливості ідентифікації значної частини мігрантів; дисонанс між системою цінностей мігрантів та системою цінностей місцевого населення; прогнозований 3 високим ступенем вірогідності зв'язок багатьох мігрантів 3 організованим екстремізмом. 
Система заходів протидії транскордонній злочинності на зовнішніх кордонах ЄС

\begin{tabular}{|c|c|c|}
\hline $\begin{array}{c}\text { Узагальнена ознака } \\
\text { заходів протидії }\end{array}$ & $\begin{array}{c}\text { Суб'скти } \\
\text { реалізації заходів } \\
\text { протидії }\end{array}$ & Опис або приклади заходів протидії \\
\hline \multirow[b]{2}{*}{$\begin{array}{c}\text { Партнерство СС } 3 \\
\text { країнами-транзитерами } \\
\text { та країнами походження } \\
\text { мігрантів }\end{array}$} & ЄС-Туреччина & $\begin{array}{l}\text { Угода від } 7 \text { березня } 2016 \text { р., яка передбачає узгоджений } \\
\text { механізм протидії нелегальній міграції }\end{array}$ \\
\hline & $\begin{array}{l}7 \text { краӥн Африки - } \\
\text { Туніс, Малі, Сенегал, } \\
\text { Нігер, Ефіопія, } \\
\text { Нігерія, Лівія } \\
2 \text { краӥни Близького } \\
\text { Сходу - Йорданія та } \\
\text { Ліван }\end{array}$ & $\begin{array}{l}\text { В основу взаємодії з цими країнами в міграційній сфері } \\
\text { будуть покладені принципи, схожі з тими, які були обрані } \\
\text { раніше при розробці угоди ЄС-Туреччина. } \\
\text { Мета - знищення функціонуючих механізмів переправлення } \\
\text { мігрантів та побудова системи охорони кордонів цих країн. } \\
\text { Наприклад, морський кордон Лівії протяжністю } 1770 \text { км } \\
\text { охороняється з надзвичайно низькою ефективністю }\end{array}$ \\
\hline $\begin{array}{c}\text { Розширення } \\
\text { повноважень морських } \\
\text { сил країн, задіяних у } \\
\text { протидії транскордонній } \\
\text { злочинності та розпов- } \\
\text { сюдження їх на прикор- } \\
\text { донні простори країн } \\
\text { максимального криміно- } \\
\text { генного ризику (Лівія) } \\
\end{array}$ & $\begin{array}{l}\text { Регіональні } \\
\text { організації в боротьбі } \\
\text { з нелегальним пере- } \\
\text { правленням мігрантів } \\
\text { і торгівлею людьми } \\
\text { та країни-члени ООН }\end{array}$ & $\begin{array}{l}\text { СБ ООН розширив резолюцією № } 2240 \text { повноваження щодо } \\
\text { огляду суден біля узбережжя Лівії у відкритому морі, якщо } \\
\text { достатні підстави вважати, що такі судна використовувалися, } \\
\text { використовуютья або використовуватимуться ОЗУ для } \\
\text { нелегального переправлення мігрантів. } \\
\text { У випадку катастроф на морі рятувальні служби ЄС } \\
\text { виловлюють потопаючих нелегалів безпосередньо біля } \\
\text { берегів Лівії і переправляють в Італію, де вони проходять } \\
\text { реєстрацію }\end{array}$ \\
\hline \multirow{4}{*}{$\begin{array}{c}\text { Операції міжнародних } \\
\text { організацій з метою } \\
\text { протидії торгівлі людьми } \\
\text { та нелегальній міграції }\end{array}$} & Інтерпол & $\begin{array}{l}\text { "INFRA Hydra" (скорочення від International Fugitive Round- } \\
\text { up and Arrest) } \\
\text { Початок - червень } 2016 \text { р. Операція спрямована на розшук } \\
\text { організаторів транскордонного нелегального переправлення } \\
\text { людей. Перелік розшукуваних включає } 180 \text { осіб з } 31 \text { країни }\end{array}$ \\
\hline & \multirow{3}{*}{ FRONTEX } & $\begin{array}{l}\text { “Triton” - спільна операція FRONTEX та італійської } \\
\text { прикордонної служби, пошуково-рятувальної служби та } \\
\text { служби реєстрації та ідентифікації мігрантів. В операції } \\
\text { одночасно задіяні кораблі, катери, авіація } 25 \text { держав-членів } \\
\text { ЄС }\end{array}$ \\
\hline & & $\begin{array}{l}\text { "Poseidon" - спільна операція FRONTEX та прикордонно- } \\
\text { поліцейських сил Греції в Егейському морі }\end{array}$ \\
\hline & & 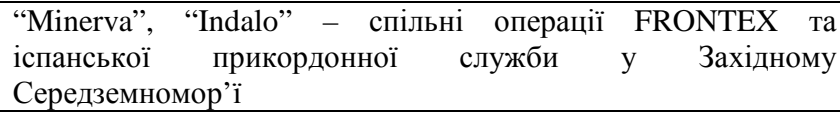 \\
\hline \multirow[t]{2}{*}{$\begin{array}{l}\text { Військово-морські } \\
\text { операції }\end{array}$} & $\mathrm{EC}$ & $\begin{array}{l}\text { EUNAFOR MED “Софія”. Початок } 22 \text { червня } 2015 \text { р., } \\
\text { мандат - до 27.07.2017 р. } \\
\text { Мета - руйнація економічної моделі перевізників мігрантів в } \\
\text { південно-центральному Середземномор”ї } \\
\text { Додаткові завдання: навчання лівійської берегової охорони і } \\
\text { сприяння у відкритому морі біля берегів Лівії здійсненню } \\
\text { ембарго ООН на постачання зброї. Повноваження: } \\
\text { ідентифікація та знищення суден, які використовуються } \\
\text { переправниками мігрантів, сприяння затриманню та передачі } \\
\text { італійським органам кримінальної юстиції організаторів } \\
\text { переправлення мігрантів }\end{array}$ \\
\hline & HATO & $\begin{array}{l}\text { В Егейському морі } 7 \text { кораблів НАТО збирають інформацію і } \\
\text { обмінюються } 3 \text { турецькою береговою охороною, грецькою } \\
\text { береговою охороною i FRONTEX. Кораблі НATO не } \\
\text { відправляють назад плавзасоби } 3 \text { мігрантами }\end{array}$ \\
\hline $\begin{array}{c}\text { Інституціональний } \\
\text { розвиток системи } \\
\text { протидії транскордонним } \\
\text { загрозам }\end{array}$ & $\begin{array}{l}\text { Європейська } \\
\text { прикордонна і } \\
\text { берегова охорона }\end{array}$ & $\begin{array}{l}\text { Головним завданням цієї новоствореної інституції } \\
\text { виявлення слабких місць в системі охорони зовнішніх } \\
\text { кордонів ЄС і надання сприяння відповідним країнам, що } \\
\text { також включає в себе боротьбу } 3 \text { тероризмом i } \\
\text { організованою злочинністю. При цьому фахівці нового } \\
\text { агентства (що створене на платформі FRONTEX) повинні } \\
\text { працювати у співпраці } 3 \text { національними прикордонними } \\
\text { службами }\end{array}$ \\
\hline $\begin{array}{l}\text { Глобалізація системи } \\
\text { спостереження за } \\
\text { кордонами Європи }\end{array}$ & EUROSUR & 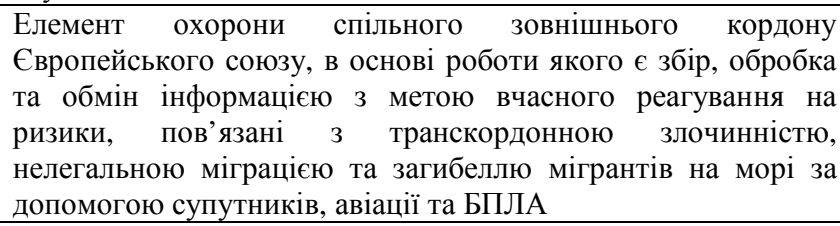 \\
\hline
\end{tabular}


3 метою протидії цим та іншим викликам Угорщина вжила таких заходів: коригування правового регулювання міграційних процедур;

посилення інженерно-технічних засобів охорони державного кордону; удосконалення

міждержавної взаємодії;

зміна рівня бар'єрності державного кордону.

На низці цих заходів зупинимося окремо та наведемо їх у табл. 2. [9].

Таблиця 2

Система пропозицій Угорщини для ЄС та відповідних організаційно-управлінських рішень щодо протидії транскордонним викликам на державному кордоні (на досвіді Угорщини у 2015-2016 рр. за даними István Shamu)

\begin{tabular}{|c|c|c|}
\hline $\begin{array}{l}\text { № } \\
\text { 3/II }\end{array}$ & $\begin{array}{c}\text { Початок } \\
\text { реалізації }\end{array}$ & Пропозицї̈ та організаційно-управлінські рішення \\
\hline 1 & Вересень 2015 р. & $\begin{array}{l}\text { Створити можливість спільним прикордонним силам ЄС охороняти кордони Греції. } \\
\text { Біженців і економічних мігрантів за межами шенгенських кордонів необхідно розділяти. } \\
\text { ЄС повинен визначити список безпечних країн для біженців. } \\
\text { Усі внески необхідно збільшити на } 1 \% \text { і скоротити витрати на } 1 \text { \%, ці } 3 \text { млрд євро } \\
\text { можуть бути використані для управління кризою. } \\
\text { Створення привілейованого партнерства } 3 \text { тими країнами, без яких не можна вирішити } \\
\text { ситуацію (особливо Туреччина). } \\
\text { Створити всесвітню квоту розподілу біженців не тільки на європейському рівні, а й у } \\
\text { всьому світі. }\end{array}$ \\
\hline 2 & Квітень 2016 р. & $\begin{array}{l}\text { Межі: необхідно забезпечити дотримання Шенгенських правил. } \\
\text { Ідентифікація: обов’язкова біометрична ідентифікація на зовнішніх кордонах. } \\
\text { Удосконалення процедури надання притулку за межами ЄС. } \\
\text { Корекція спільної європейської системи притулку. } \\
\text { Угоди: укладення угоди про реадмісію та повернення у країни походження і транзиту. }\end{array}$ \\
\hline 3 & Квітень 2016 р. & $\begin{array}{l}\text { Повернення: повернення в безпечні країни транзиту та походження. } \\
\text { Обумовленість: різні політики ЄС повинні забезпечити цілі міграційної політики. } \\
\text { Допомога: фінансова та інша підтримка для цільових країн. } \\
\text { Безпечні країни: загальний європейський список безпечних третіх країн. } \\
\text { Добровільність: дозволяти демографічні та трудові проблеми ринку на основі } \\
\text { (добровільний прийом) автономного рішення держав-членів. }\end{array}$ \\
\hline
\end{tabular}

Висновки. Таким чином, вважаємо, що подальші дослідження слід сфокусувати на оцінюванні ефективності таких елементів інституційної системи протидії транскордонним загрозам як Свропейська прикордонна і берегова охорона, застосування сил і засобів військово-політичного альянсу НАТО, механізм інформаційної взаємодії між прикордонними відомствами держав-членів Європейського союзу - EUROSUR.

\section{СПИСОК ВИКОРИСТАНОЇ ЛІТЕРАТУРИ}

1. The Rome Declaration. 25.03.2017. [Електронний pecypc]. - Режим доступу : http://www.consilium. europa.eu/press-releasespdf/2017/3/47244656633_en.pdf.

2. Філіппов С. О. Структурна конфігурація системи протидії транскордонній злочинності на зовнішніх кордонах Євросоюзу / С. О. Філіппов // Правова держава. 2017. - № 25. - С. 178 - 184.

3. S. Carrera and L. Den Hertog A European Border and Coast Guard: What's in a Name? (March 8, 2016). CEPS Paper in Liberty and Security in Europe.

Available

SSRN: https://ssrn.com/abstract=2745230.

4. A European Border and Coast Guard and effective management of Europe's external borders / Strasbourg, $\operatorname{COM}(2015) \quad 15.12 .2015673$ final [Електронний ресурс]. - Режим доступу:
http://europa.eu/rapid/press-release_IP-156327_en.pdf.

5. Regulation (EU) 2016/1624 Of the European Parliament And of the Council of 14 September 2016 [Електронний ресурс]. - Режим доступу: http://frontex.europa.eu/assets/Legal_basis/European _Border_and_Coast_Guard.pdf.

6. Заявление по итогам встречи на высшем уровне в Варшаве обнародовано главами государств и правительств, участвующими в заседании Североатлантического совета в Варшаве 8-9 июля 2016 р. [Електронний ресурс]. - Режим доступа : http://www.nato.int/cps/en/natohq/official_texts_ 133169.htm?selectedLocale=ru.

7. Filippov, Stanislav. Dynamics and Geographical Distinctions of Crime connected with Migrants' Moving to Europe on Different Routes / S. Filippov / NATO Science for Peace and Security Series - E: Human and Societal Dynamics Addressing Security Risks at the Ukrainian Border Through Best Practices on Good Governance: Editors R. Kęsek at al. - 2016. Amsterdam: IOS Press. Volume 129. P. 21-27.

8. Risk Analysis for 2016: [Текст]. Warsaw,

FRONTEX. 2016 - 72 p.

9. István Shamu Nyilvános előadás / Шаму, Иштван. Материалы публичной лекции в ПКРС ОБСЕ. Душанбе, 2017. 
Стрельбицкий М. П., д.ю.н., профессор ${ }^{1}$;

Филиппов С. О., к.психол.н., доцент ${ }^{2}$

1 - Национальная академия Службы безопасности Украины, Киев;

2 - Национальная академия Государственной пограничной службы Украины имени Богдана Хмельницкого, Хмельницкий

\section{Изменение конфигурации системы противодействия трансграничным угрозам на границах Евросоюза}

Резюме. Основное внимание в статье уделено мерам противодействия трансграничным угрозам в $\mathrm{EC}$, в частности: созданию Европейской пограничной и береговой охраны на платформе FRONTEX; применению сил и средств НАТО в сугубо полицейской операции в Эгейском море; механизму информационного взаимодействия между пограничными ведомствами государств-членов EC - EUROSUR; операции международных институтов, направленые на содействие пограничным службам.

Ключевые слова: трансграничная преступность, организация нелегальной миграции, система противодействия трансграничным угрозам, Европейская пограничная и береговая охрана, НАТО.

\section{Strelbitsky, Ds.M, professor ${ }^{1}$;}

S. Filippov, Ph.D, assistant professor ${ }^{2}$

1 - National academy of the Security Service of Ukraine, Kyiv;

${ }^{2}$ - National academy of the State Border Guard Service of Ukraine named after Bogdan Khmelnitsky, Khmelnitsky

\section{Structural Change Configuration of the System of Combating Cross-Border Threats} at the Borders of the European Union

Resume. The article focuses on measures to combat transponder threats in the EU, in particular: the establishment of the European Border Guard and Coast Guard on the FRONTEX platform; the use of NATO forces and assets in a strictly police operation in the Aegean Sea; the mechanism of information interaction between the border agencies of the EU member states - EUROSUR; The operations of international institutions are aimed at assisting the border services.

Keywords: cross-border crime, organization of illegal migration, system of combating cross-border threats, European Border and Coast Guard, NATO. 